\title{
EFL for Development
}

David Cooke

This paper examines the relationship between teaching English as a foreign language (EFL) and development issues. ${ }^{\prime}$ An analysis of the key areas of developmental EFL is offered. In addition, English language teaching (ELT) in developing countries is discussed from the point of view of its effects on the host culture. Throughout the article, suggestions are made for ensuring that developmental EFL/ELT becomes a productive force within a host country.

\section{DEVELOPMENT AND DEPENDENCY}

Some years ago, a Third World diplomat pleaded with a Western aid agency, "Please don't send underdeveloped people to developing countries." He had in mind those who were ill-prepared both for their occupations and for development.

Since then, there has been an energetic debate over development, of which more in a moment. But first, a word from one of Canada's aid sponsors. CUSO's Director, Chris Bryant (1985), offers the following check-list for rating development projects:

1. Does the project help poor people? If not, why do it? Often projects help people back in Canada more.

2. Is the project aimed at a definable group, e.g., is it going to help women? Projects can't aim at everything.

3. Do local people control the project?

4. Does the project use local people?

5. Is the project based on local material resources, e.g., does it need external funds?

6. Is the project sustainable in the long term?

7. Is the outside help involved a limited part of the project? Is it habit-forming or not?

8. Does the project shift power to poor people?

There are various reasons for Canadians to become involved in English language teaching (ELT) and education abroad (Martin, 1986). But the overriding concern must surely be that Third World needs are urgent, pervasive and devastating, in ways that even the Ethiopian famine coverage didn't reveal. Against this setting, Bryant suggests we should be really critical about our own involvement. What form, then, does our involvement take? 
In the early post-war period, Western aid mirrored Western notions of capitalist growth, with large-scale industrial projects, of a capitalintensive nature, increasingly turning to high-tech, machine technology. The result has been a growing division between rich and poor, alienation of large segments of society, strengthening of the power and wealth of small elites, and growing dependencies on the West (Adams \& Solomon, 1985; Carty \& Smith, 1981; Clarke \& Swift, 1982; Hayter, 1971, 1981; Payer, 1974). In other words, Third World countries have started to resemble our own quite a lot, and have become locked into foreign Western economies.

This growth model, Everett Rogers (1976) points out, can be contrasted with an emerging self-reliance model, which seems to be built on trying to meet basic needs-a kind of extensive social welfare concept. To paraphrase Rogers somewhat, development for self-reliance has characteristics like the following:

- the greatest good for the greatest number;

- independence, self-sustenance, ingenuity (e.g. the literacy projects of Nicaragua and Cuba);

- popular participation (Kidd \& Byram, 1977, 1978);

- local liaison and orientation: use of local resources, indigenous solutions, local control (Kossick, 1983);

- appropriate solutions to real problems.

If the self-reliance model is more valid than the growth model, then the Third World should be aware of the dangers of Canadian involvement, since our national movers and shakers clearly have something else in mind when they think of development: "Northerners need higher education and a willingness to participate in a wage economy," says Charles Hetherington of Panarctic, "if they are to join in the mainstream of Canadian economic activity." At the same gathering, David Crombie, then Canada's Minister of Northern Affairs, first made an obligatory bow to ecology by announcing that the Government would respect the environment. But then he basically backed up the President of Panarctic Oils, "We will develop the North." 2 The direction of such remarks clearly has nothing to do with local self-reliance and everything to do with huge projects to extract resources. Since oil greases the economy, it is not surprising that Canada's North remains a colony.

By contrast, progressive development in Third World settings means betterment in meeting basic human needs. It means continuing progress for the mass of society in meeting physical, social, political, economic, and moral needs, so as to promote self-reliance, responsibility and sharing of resources. The question facing the individual and the development agency is, "What is the most progressive response to the situation in a Third World country, and for that matter, back home in the West?" 


\section{DEVELOPMENTAL EFL}

One of the critical areas of developmental English as a foreign language (EFL) is the upgrading of teachers, curricula, and materials. Improving teachers' skills can happen in a variety of ways: fostering small teams of expatriate and local counterparts, working together to meet the language teaching needs of a school; establishing programs of formal teacher education for trainees; encouraging informal teacher workshops. A different side to teacher upgrading is carefully constructed curricula and materials that can serve as models for teachers in their own teaching, in preparation for classes, and in more long-term planning.

A second and obviously related area of EFL is the promotion of indigenous EFL, i.e., English language teaching (ELT):

- that is locally-oriented and appropriate to local conditions;

- that involves local liaison between relevant parts of the activity (see the "web" below);

- that requires local control;

- that meets the needs of the country;

- that resolves the tension between orientation to local culture and content and the foreignness of EFL.

All this is much easier said than done. Significantly, a number of different sectors of ELT are inevitably inter-related; therefore, they influence each other, as is implicit in the following diagram. One outcome is that ELT may well be only as good as its weakest link.

\section{The ELT Web}

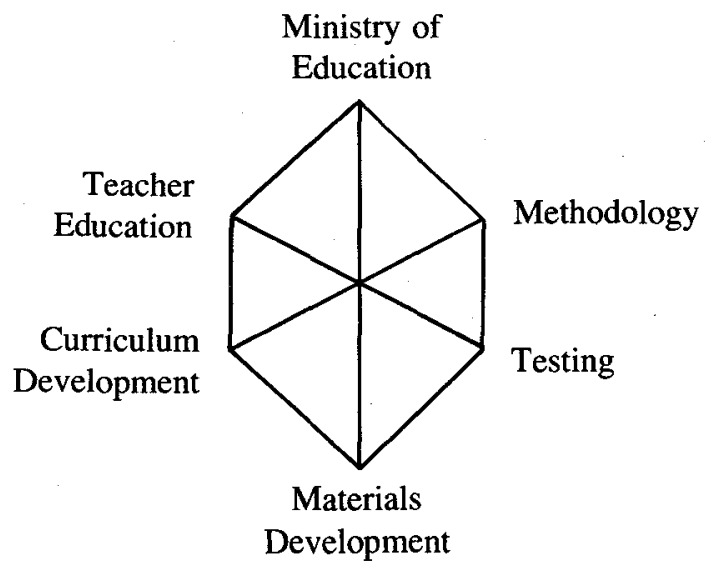


To illustrate the interaction between different parts of the web, we could take the case of the language teaching methods used. The dominant form of language teaching in a given country may be, let us say, grammar-translation in some form. Meanwhile, some of the country's teacher education may be promoting different methods or approaches. However, the context in which the teacher education takes place, namely the schools, puts a brake on change. Teacher trainees may do their practice teaching in schools where the practice and examples all around them confirm existing trends and discourage innovation. If indeed methodological change is necessary, it will likely require concerted agreement and effort by other parties in the web: e.g., direction and support from the Ministry of Education; the development of curricula and materials that give new models; exams which do not simply reaffirm traditional practices and force teachers to follow old ways so as to try to get students through the year-end trial, regardless of whether it's in their educational interest.

It follows that a third area of developmental EFL is the promotion of democratic involvement in ELT. For example, a materials development project is an opportunity for the project team to encourage local teachers to take part, possibly together with other organizations, such as women's groups, cultural associations, youth groups and so on. Moreover, some countries have rich oral histories which are now being recorded and preserved. Such resources might well be incorporated into language projects in creative and productive ways.

Naturally, ELT has fourthly to provide certain basic skills in language and language learning, which could include at least the following: listening, speaking, reading and writing; also editing and monitoring language and language use; inferencing; and the crucial skill of learning to learn, so that students are not tied to particular teachers for their learning, nor dependent on a given program as their only source of language progress.

Fifth, alongside basic skills, ELT could also promote critical education that explores, investigates, challenges, and assesses the topics and information it deals with. For far too long, in any case, ELT has omitted significant content in its courses. Subject matter has often been merely a means to the end of learning language, and language courses have therefore lacked substance. ELT is now starting to move to a contrary procedure, in which language becomes a means of dealing with content, because the topics treated are of genuine human concern, related to people's real lives and needs. To do justice to the urgent issues of people's lives in Third World settings requires critical appraisal, serious debate, and questioning, when dealing with matters like the following: the status and treatment of women in society; the provi- 
sion of food, water supply and adequate housing; animism in some communities; and basic health-care in many countries.

Accordingly, a final area of developmental ELT is individual and group problem-solving, both by and among students and those administering or delivering ELT. At its best, in other words, ELT would go beyond simple training in using the tongue to a stage of language proficiency that enables people to confront real-life issues and to derive solutions.

There is an obvious objection to some of the above procedures. Why not use the learner's mother tongue to talk about their own reality? One answer is that English has become a major world language that reflects a great deal of current development in science, technology, aid, and other areas of life. As such it becomes an inevitable medium of exchange between local and foreign representatives. It is often one of the languages for conveying instructions, directions and basic information in print. And it therefore becomes a means of attaining basic source material, a process which is being reinforced by electronic communication. The net effect is that for many countries, certain sectors of society are likely to have some call upon English in areas such as trade, aid, business, commerce, industry, diplomacy, security, the military, communications, travel, and transport.

\section{STEPS IN DEVELOPMENT}

One can envisage a series of steps in moving towards development. The most basic level for the expatriate is to simply fill a gap: the foreigner is a warm-blooded means of supplying a necessary skill. There's no question that this is valid and valuable and that both parties can benefit. But from the viewpoint of promoting an on-going process within a country, the expatriate's year or two abroad may be no more than marking time.

A second activity, often related, is to supply resources such as materials, curricula, tests, guidelines, and equipment. But this kind of delivery is problematic, since the resources may or may not promote extension and progress. Indeed, in some cases, external materials succeed in underdeveloping the local ELT. As an expatriate once said of some Western materials, "Why not use them, since it's all done for you?" And therein lies the problem: the subject matter, orientation and methodology are all done for you, with the result that indigenous materials production may stand still. Alternatively, the foreign materials, even though quite possibly prepared for conditions and needs that differ from those of the Third World country, may strongly influence local materials production, because they exist in a satisfying and packaged 
form. The outcome can easily be stagnation, inertia, or a misleading direction in ELT activity. Of course, it is just as conceivable that the imported materials may prove the right sort of stimulus, opening up new ideas and different avenues of approach. The moral is not to assume the use of foreign materials will automatically produce this positive series of results.

A third step known under the buzz word of "multiplier effects" is the process of handing on skills. This very necessary training function can occur in many aspects of teaching, in teacher education, in the development of materials, curricula and tests, and in educational planning. Its obvious effect is to build up local skills.

As such, skills-training is a stepping-stone to the ability to solve problems through local responses that truly meet the needs of ELT. This process may be a joint activity of expatriate and local representatives, but at its best, it must enable the Third World inhabitants to act independently.

\section{THE EFFECTS OF DEVELOPMENTAL EFL}

The above steps imply that there is something vital and productive about developmental EFL. In a word, it is building-the process of building for the future; building for self-reliance; building for national reconstruction. This building is carried out in several ways: through mobilizing people to take part cooperatively in EFL activity; through seeing EFL as a service to the needs of society; through making English available as a tool for understanding, for providing necessary information that can help to solve pressing problems, for promoting awareness of ideas and practices abroad that may be adapted to the local scene.

For the pragmatic strain within us, there is also a benefit back home. Seeing how ELT can benefit other societies than our own prompts us to reflect on ESL here in the West. For instance, ELT and EFL are clearly activities that can reach beyond the individual teacher, student, or class to the community and to society, and can therefore recognize group needs. (In North America, given the stress on individualism and the silence on collective action, it is tempting for teachers to fixate on their own particular students and miss broader societal concerns.) Moreover, the more we conceive of ELT as a coordinated process of pooling teachers' experience and insight, the more chance we have of strengthening our own home-grown community of EFL teachers and developers. In other words, our Third World experience can make us conscious of development both at home and abroad.

The upbeat side of EFL as development implies a downside resulting from not seeing EFL in developmental ways. Ignoring the potential 
developmental aspect of EFL is not necessarily a passive or benign process. It may have certain active and negative effects. Here are some examples. Nondevelopmental EFL can create dependencies, e.g., on Western materials, technology, and hardware like language labs, with all the resulting problems of inappropriacy and lack of supply. It can create a vacuum, after an expatriate merely fills a gap without providing in some way for local instructors or developers to take part in progressive, continuing involvement. It can create a backslide, through using an imported teaching strategy which blocks local initiative. It can create a beachhead to usher in Western values through education, especially in the content of materials, whether they come from textbooks or found materials such as Macleans, Time and Newsweek.

\section{CONCLUSION}

One belief that underlies the discussion above is that EFL is not an island. It can have an impact upon a nation, for good or evil. It raises questions regarding the use of resources in society, questions such as who can reasonably have access to English language learning: small, selected groups or the mass of a population? And it forces the issue that education in this case is not just an application of language teaching technology, but a significant cultural intervention which opens up an array of awkward choices.

Hence, Mather (1985) and Rogers (1982) ask the disturbing question of whether EFL is always entirely necessary. The earlier discussion above is based on the idea that if a particular country decides to institute programs in EFL/ELT, there are various ways in which the country can productively operate. But in certain settings, it may well be that English is a questionable commodity: it may raise totally false expectations (Rogers, 1982), or it may be that in certain rural areas, the effort of providing basic educational skills should not be dissipated by the demanding and rather unrewarding chore of ELT. At the least, then, a country needs convincing reasons for launching into ELT, and some evidence that the accompanying use of resources is clearly in the national interest.

Finally, there is a key question for EFL teachers to face. What is the legacy of EFL? To the extent that ELT exists in a country, does it promote general well-being in some way, or does it merely shere up a small elite? Bryant of CUSO would ask, "Does it help poor people?" Does it, moreover, help to tie a country into unequal economic unions or the imperialist designs of another nation or power bloc (remembering that English is a major world language of powerful countries)? Does English in some way help promote self-determination, progressive social 
movements, some enhanced scope for education, information and enlightenment? If not, are there other benefits it provides, or is it a costly luxury of minimal social benefit?

If a country can escape the traps just outlined, then there is space for considering how EFL can become a productive, developmental force.

\section{NOTES}

1. This article grows in part out of experience in a teacher education program in Mozambique in 1984, funded by ICDS of CIDA and York University, with support from CUSO.

2. (1985, November). The Globe and Mail.

\section{REFERENCES}

Adams, P. \& Solomon, L. (1985). In the name of progress: The underside of foreign aid. Toronto: Energy Probe Research Foundation.

Bryant, C. (1985, November). Development. Keynote Address at the EFL Symposium, TESL Canada Conference, Toronto, Ontario.

Carty, R. \& Smith, V. (1981). Perpetuating poverty: The political economy of Canada's foreign aid. Toronto: Between the Lines.

Clarke, R. \& Swift, R. (Eds.). (1982). Ties that bind: Canada and the Third World. Toronto: Between the Lines.

Hayter, T. Aid as imperialism. (1971). Harmondsworth: Penguin.

Hayter, T. The creation of world poverty: An alternative view to the Brandt Report. (1981). London: Pluto Press, in association with Third World First.

Kidd, R. \& Byram, M. (1977). A Botswana case study: Popular theatre and development. Convergence, 10, 2, 20-31.

Kidd, R. \& Byram, M. (1978). Popular theatre: A technique for participatory research. Working Paper No. 5. Participatory Research Project: Toronto.

Kossick, D. (1983, November). The role of cooperatives in basic urbanization programs in Maputo, Mozambique. Settlements Information Network-Africa (SINA) Second Workshop. Nairobi: Mazingira Institute.

Martin, I. (1986). Developing Canadian English language strategy. CUSO Forum, 4, 1, 19.

Mather, J. (1985, November). Is there a need for EFL? Paper presented at the EFL Symposium, TESL Canada Conference, Toronto, Ontario.

Payer, C. (1974). The debt trap: The IMF and the Third World. Harmondsworth: Penguin.

Rogers, E.M. (1976). Communication and development: The passing of the dominant paradigm. In E.M. Rogers, (Ed.), Communication and development: Critical perspectives. Beverly Hills, CA: Sage.

Rogers, J. (1982). The world for sick proper. ELT Journal, 36, 3, 144-151.

\section{THE AUTHOR}

David Cooke teaches English language and Education at Glendon College, York University, Toronto. He has taught English and ESL/EFL teacher education in Britain, Canada, Europe, Mozambique, New Zealand, and the People's Republic of China. 